\title{
The Role of Marketing and Advertising in the Legal Profession
}

A Breytenbach

Department of Marketing, Pretoria Technikon

\section{E J North}

Department of Marketing and Communication Management, University of Pretoria

\section{ABSTRACT}

The majority of South African attorneys do not enjoy the benefits that may be derived from the marketing and advertising of their services. They seem to be unaware or do not make use of marketing and advertising opportunities to promote their firms and the services they render. The lack of marketing knowledge, ignorance of the value of advertising, as well as the perception that advertising will cause unnecessary costs, are reasons why many legal firms are not marketing oriented. This paper reports the results of an empirical study done to determine the role of marketing and advertising in the legal profession in South Africa.

JEL M37

\section{INTRODUCTION}

In today's competitive business environment, legal practitioners can no longer

... count on their reputation and country club contacts to obtain a steady stream of clients (Bloom 1984: 102).

In the marketing of both products and services, many factors such as technological innovation, globalisation, improved quality and customer service, and ever changing consumer needs, require that organisations become more marketing oriented. Service professions such as lawyers, doctors, auditors, architects, and engineers are discovering that the adoption and implementation of a marketing philosophy is a vital factor for business and organisational success. An increasing interest in marketing is being witnessed worldwide by professional practitioners. According to Bradley (1995: xxviii) marketing " ... is a concern for all people and organisations at all times". In order to deliver value 
to clients, it is suggested that even attomeys apply marketing principles in their firms, and be more customer focused rather than cost driven.

The need for attorneys to become more marketing oriented was further stimulated by the worldwide lifting of restrictions and rules on the advertising and promotion of legal services. The adoption of a marketing philosophy and implementation of marketing strategies have become almost inevitable for attorneys and others in the legal field. According to Coetzee (1992: 34), the abolishment of regulations on the advertising of legal services and the publicity surrounding this issue, have sparked an interest by attorneys to advertise and market their services. The question is however: how marketing oriented are South African attorneys, and to what extent do they apply marketing principles and strategies in their firms?

\section{PROBLEM STATEMENT}

Although attorneys now have much more freedom to promote their business activities, the effect of this has not yet been investigated in South Africa.

An empirical research project was therefore conducted primarily to determine:

- what impact the abolishment of marketing regulations has had on the marketing and advertising activities of attomeys; and

- how attorneys use advertising as a marketing tool.

Secondary objectives of the study were inter alia to look into the following matters:

- the level of marketing knowledge and expertise in firms of attorneys;

- the relationship between the age, size and geographic location of the firm and its marketing activities;

- the media in which they prefer to advertise;

- the reasons why some of them do not advertise;

- the perceptions of attorneys regarding the possible advantages and disadvantages of advertising; and

- whether advertising has an influence on fees.

\section{LITERATURE REVIEW}

\section{Profession}

As professional people, attorneys render services to the community, Traditionally there is a perception that the legal profession should not adopt commercial methods and tactics to promote their services (Wilson 1984: 19). 
Many argue, for example, that it is wrong (unethical) to advertise. Sinclair (1987: 129) and Attanasio (1984: 500) state the following reasons why it is unprofessional for legal practitioners to advertise their services:

- It harms the image of the firm.

- Advertising increases fees.

- Advertising leads to competition and eventually to price wars.

- It is unnecessary to advertise because there will always be a demand for this kind of service.

- Clients should be protected against unfair competition.

- Advertising makes it difficult for firms to maintain objectivity and integrity.

The Concise Oxford Dictionary (1979) defines a profession as follows: "vocation or calling, especially one that involves some branch of advanced learning or science". Some characteristics or "trademarks" of the legal profession are the following (Bennion in Wilson 1972: 4):

- Thorough academic training and assessment.

- Advisory role.

- Main aim is to render professional services.

- Representative bodies to support members and set standards.

- Code of ethical conduct laid down by professional institute.

The legal profession demands a very high standard of integrity and know-how of its members. Unfortunately, there is a perception among many people that the legal profession is characterised by self-enrichment and unrealistic profit seeking. Does this then imply that advertising is taboo? In a well-known American case (Bates vs State Bar of Arizona, 433 U.S. 30, 1977) as discussed by Elliot (1986: 23), it was found that factually correct information in advertisements informing the public about routine legal services are asceptable. This led to the lifting of restrictions on the advertising of legal services in the United States, England (1984) and eventually in South Africa (1990).

\section{Marketing}

According to Bradley (1995: 45), marketing entails providing, communicating and delivering value to customers. The identification of customer value and communication of the benefits of the services rendered by attomeys (Wilson 1984: 2), therefore fit in well with the traditional viewpoint of the marketing concept. The competitive advantage that can be gained by adopting a marketing philosophy for the firm is neatly summarised by Bloom (1984: 106): "Professional service firms can emphasise three attributes or personality features to set themselves apart: 'grey hair' (more experience, specialisation, credibility and contact), 'more brains' (better solutions to problems), and "superior procedures"'. 
However, for many professionals in the legal field, marketing is a new concept. The implementation of marketing principles and strategies also pose problems for these professionals. Wannop (1998: 3) argues that some legal professionals see marketing only as advertising, selling and research. More misconceptions listed by Wannop are the following:

- Marketing is in essence an unprofessional activity.

- The activities of marketers are "unworthy".

- The marketing endeavour becomes too commercialised.

- The costs involved in the marketing of services are too high.

\section{Marketing of services}

There is a growing agreement among academics and practitioners that the socalled four traditional P's in marketing (product, price, place, and promotion) are not sufficient to take care for the marketing of services. According to Booms \& Bitner (Kotler, 1997: 472), and Bradley (1995: 89) three more P's must be added to the mix, namely participants, physical evidence and processes. The participants refer to the training of personnel, interpersonal behaviour, and negotiations with customers. Environmental aspects such as the furnishings, colour, layout of the buildings, and other tangible clues are included in physical evidence. The processes refer to the flow of activities, policies, and general procedures in the organisation.

Churchill and Peter (1998: 288) summarise the nature and importance of services marketing as follows: “... service marketers have an on-going personal relationship with their customers, the success of a service organisation often depends on its ability to retain, not just attract, customers". In the legal profession, therefore, the functional quality of services rendered is of utmost importance.

\section{Advertising}

Advertising involves an important marketing communications activity. Companies do not only advertise their products and services, but also promote themselves in a very competitive way.

The Marketing Guide for Attorneys (Association of Attomeys 1990: 9) defines advertising on three levels:

- Advertising: “... a paid form of non-personal communications by means of TV, radio and publications"

- Institutional advertising: "...advertising on behalf of a profession at a national level to increase awareness of and promote the image of the profession" 
- Individual advertising: “...advertising by individual practices to increase awareness of the practitioners' activities and promote the image of the practice".

Advertising by attorneys takes place on three levels, namely at national level, at provincial level and individually.

Findings of an informal study by the National Productivity Institute (NPI) in 1990 indicate that there is a need for advertising by professional people in the legal field. Two main problems were however identified, namely:

- the public generally has a faulty (and sometimes negative) perception of the services rendered by lawyers; and

- a negative perception exists in relation to fees, use of language, relationships with customers and the physical appearance of offices and buildings.

Unfortunately, many of these perceptions rely on hearsay and are not based on first-hand experiences. Negative publicity in the mass media may also contribute to the negative perception.

The above-mentioned problems and other factors that hamper the positive communication of legal services (such as a lack of marketing knowledge, and the strict professional code of the profession) emphasise the need for legal firms to engage in sound and effective marketing practices. The modus operandi of a research project, which was conducted to determine how legal practitioners in South African approach and apply marketing strategies in their firms, will now be discussed.

\section{METHOD}

An exploratory investigation was conducted to determine the role of marketing and advertising in the legal profession. A self-administered questionnaire was used as the data collection instrument.

\section{Sample size and data collection procedure}

All the practising attorney firms in South Africa represented the population for this study. An address list of these firms was obtained from the Butterworths Legal Diary (1997) according to which 4497 firms were registered in South Africa in 1997. 
A probability sample of $11.11 \%$ of the population drawn from all the provinces in South Africa resulted in the dissemination of 500 questionnaires. A response rate of $20 \%$ was envisaged.

The reasons why a mail questionnaire was used to obtain the information needed are as follows:

- the sample had to be representative;

- the geographic location of the firms necessitated this method of data collection; and

- the quality of response should be more satisfactory if firms had enough time to complete the questionnaire.

Respondents were requested to complete the questionnaire by way of closed responses on a five-point Likert scale. The questionnaire was also pretested to eliminate possible errors.

\section{Data capture and analysis}

The Excel spreadsheet was used for data capture on the computer. Questionnaires were coded by assigning numerical values to the various responses.

The CSS Statistica package was used for analysis of the data. Frequency tables provided the basis for descriptive analysis of the data. Cross tabulations and tests of significance were also executed.

\section{RESULTS}

One hundred and seventy four $(34.8 \%)$ of the possible 500 respondents returned their questionnaires. This is considered to be a satisfactory response rate for a mail survey.

\section{Size, location and age of firms}

The majority of the firms in the sample $(65.5 \%)$ were classified as "older" firms, that is, in business for more than 11 years. No evidence could be found that older firms advertise more than younger firms. Older firms, however, seem to advertise mostly in newspapers. As could be expected, most of the firms (89.1\%) operate in urban areas. Firms in urban areas are more inclined to advertise than those in rural areas. This tendency is supported by the findings of a previous study (Van Rensburg 1992: 72). Most of the firms (83\%) who use the Internet as a medium are located in urban areas. 
No relation exist between the size of a firm and the advertising activities they engage in. Larger firms, however, use a greater variety of media for advertising.

\section{Marketing knowledge}

Almost one half $(49.4 \%)$ of the respondents indicated that they do not have any marketing expertise or knowledge in the firm. Those firms who do have marketing knowledge (12.7\%) gained it through formal training. Figure 1 shows the relationship between marketing knowledge and use of advertising. For example, almost $18 \%$ of the firms who gained marketing knowledge through self-study make use of advertising. More than one-third (37\%) of the firms who have no marketing knowledge do not advertise at all.

Figure 1 Relationship between marketing knowledge and use of advertising

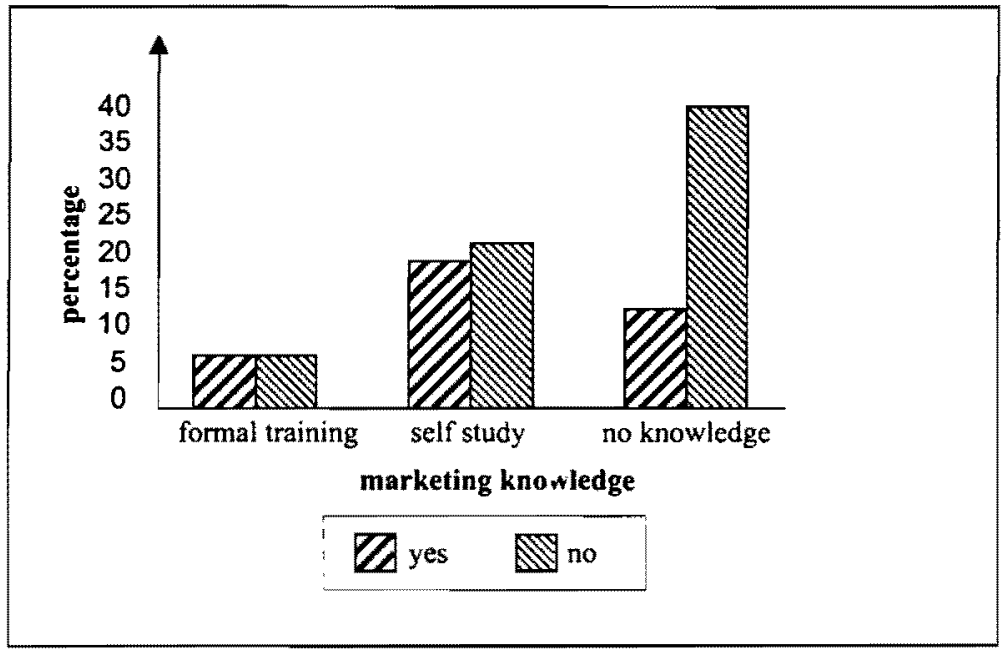

\section{Advertising media}

According to the information in Table $1,75 \%$ of the respondents make use of print media advertising. Most of these respondents use newspapers as a medium. Almost $14 \%$ of the firms use the Internet as a medium to advertise their services. 


\section{Table 1 Preferred advertising media used by firms}

\begin{tabular}{|l|c|c|}
\hline \multicolumn{1}{|c|}{ Medium } & Frequency & Percentage \\
\hline Commercial publications & 14 & 16 \\
\hline Newspapers & 49 & 56 \\
\hline Financial publications & 3 & 3.5 \\
\hline Internet & 12 & 13.5 \\
\hline Other & 10 & 11 \\
\hline Total & 88 & 100 \\
\hline
\end{tabular}

Respondents gave two main reasons why they do not make more use of advertising in the various media, namely, the lack of marketing knowledge and the high cost of advertising.

\section{Attitudes towards marketing and advertising}

Answers by respondents relating to their attitudes and possible future marketing activities, showed the following:

- Almost $63 \%$ are of the opinion that they must advertise, even though they do not necessarily want to recruit new clients.

- Marketing in general can be advantageous (79\%).

- Almost $70 \%$ believe that advertising does not exploit the public.

- Word-of-mouth advertising must be supplemented with other forms of advertising (70\%).

- Seventy per cent of the respondents are of the opinion that marketing and advertising can raise the demand for legal services.

\section{CONCLUSION AND RECOMMENDATIONS}

The results of this study indicate that many attorneys do not utilise the benefits that can be derived from the marketing and advertising of their services. They seem to be unaware of, or do not make use of the marketing and advertising opportunities to promote their firms and the services they render. Many, however, also indicated that they would make more use of advertising in the future.

The lack of marketing knowledge and ignorance regarding the value of advertising, as well as the perception that advertising will cause unnecessary cost, are reasons why many legal firms are not marketing oriented. Some 
probably may also believe that advertising is not necessary because their services are of a high quality.

Firms in urban areas advertise more than those in rural areas, probably due to the fact that they face competition.

A large number of firms also believe that attorneys in general do not reflect a positive image to the broad public. The need to compile and implement a corporate communication strategy, in order to build and improve positive longterm relationships with various publics, seems to be a matter that needs urgent attention.

Future research can inter alia focus on the following:

- Qualitative research (e.g. focus groups) should be undertaken to determine, for example, the reasons why legal firms are inert in adopting marketing strategies.

- The possibility to include marketing as a module in the curriculum for the training of attorneys must be investigated.

- In-service-training courses on marketing for attorneys could be developed.

- The role of culture in the marketing of legal services in South Africa should be investigated.

- Research must form the basis for addressing ethical issues in advertising by attorneys.

\section{REFERENCES}

1 ASSOCIATION OF ATTORNEYS (1990) Marketing Guide for Attorneys, Johannesburg.

2 ATTASANIO, J.B. (1984) "Lawyer Advertising in England and the United States", ILP -32AM.J Compl, 32.

3 BLOOM, P.N. (1984) "Effective Marketing for Professional Services", Harvard Business Review. September - October.

4 BRADLEY, F. (1995) Marketing Management: Providing, Communicating and Delivering Value, Prentice Hall, London.

5 BUTTERWORTHS LAW DIARY \& DIRECTORY (1997) Butterworths, Durban.

6 COETZEE, J. (1992) "Prokureurs Stel Bemarkers Aan", Finansies en Tegniek, Februarie.

7 ELLIOT, R.G. (1986) "Trolling for Clients Under the First Amendment: It's Hard to Keep a Good Solicitor Down", IPL 60 Conn. B.J.,60.

8 KOTLER, P. (1997) Marketing Management. Analysis, Planning, Implementation and Control, $9^{\text {th }}$ ed., Prentice Hall, New Jersey 
9 SINCLAIR, R. (1991) "Marketing Freedom: the Pressures for Change", De Rebus, July.

10 THE CONCISE OXFORD DICTIONARY (1979) Oxford University Press.

11 VAN RENSBURG, J.A. (1993) "Die Rol van Advertensie in die Prokureursprofessie van Transvaal", Navorsingsverslag, Nagraadse Skool vir Bedryfsleiding, UNISA.

12 WANNOP, D.C. (1989) Marketing Legal Services, Carswell, Toronto.

13 WILSON, A. (1972) The Marketing of Professional Services, McGrawHill, London.

14 WILSON, A. (1984) Practice Development for Professional Firms, McGraw-Hill, London. 